\title{
Molecular characterization of heat shock protein 70 gene in Iraqi buffalo
}

\author{
H.N. Habib \\ Department of Animal Production, College of Agriculture, University of Basra, Iraq, hassan.nima@uobasrah.edu.iq
}

(Received April 21, 2019; Accepted June 16, 2019)

\begin{abstract}
The heat shock protein 70 (HSP 70) has important roles in protecting cells and keeping them alive when exposed to different stress conditions. The polymorphism of the $h s p 70$ gene could be linked with the ability of stress tolerance. This study aimed to determine the polymorphism of the $h s p 70$ gene in Iraqi buffaloes and study bits effects on the resistance to stress. This study was conducted during from November 2018 to February 2019. The number of buffalo females used was 35 at the age of 4 - 6 years, which belonged to the local farmers from Basra city, Iraq. The DNA was extraction from the blood samples then the polymerase chain reaction (PCR) amplification was performed. The DNA sequences were analyzed by using bioinformatics analysis. The results of the molecular analysis showed that there were two groups of the $h s p 70$ gene as a compare with the same genes in GenBank due to silent and missense mutations. Based on these findings, it can be concluded that the Iraqi buffaloes have adapted to the surrounding environmental conditions as a result of the action of HSP 70 proliferation. The $h s p 70$ gene was a useful biomarker of stress tolerance in buffaloes.
\end{abstract}

Keywords: $h s p 70$ gene, Buffalo, Environmental stress, Polymorphism

Available online at http://www.vetmedmosul.com, (C) 2020, College of Veterinary Medicine, University of Mosul.

This is an open access article under the CC BY 4.0 license (http://creativecommons.org/licenses/by/4.0/).

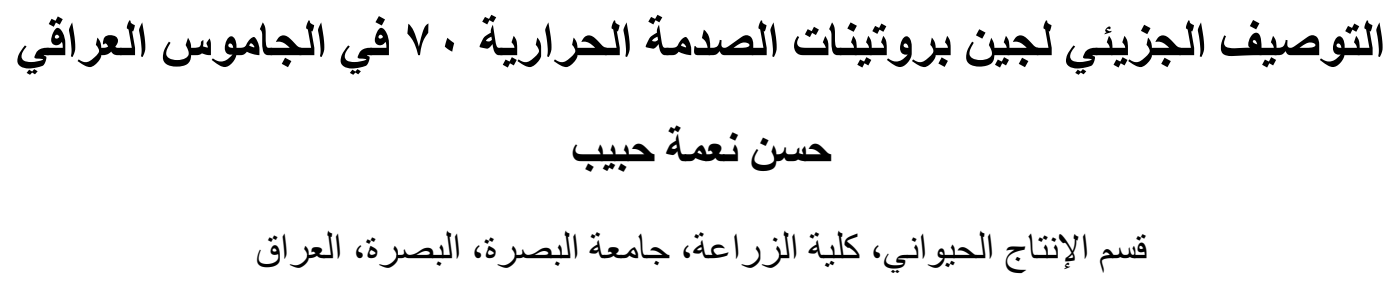

تلعب بروتينات الصدمة الحرارية • • دور مهم في حماية الخلايا و إبقائها على قيد الحياة عند تعرضها لظروف الإجهاد المختلفة.

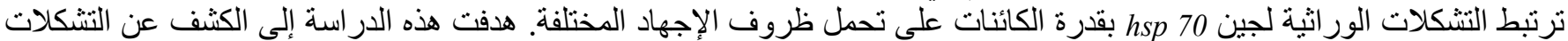

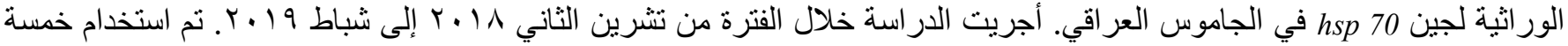

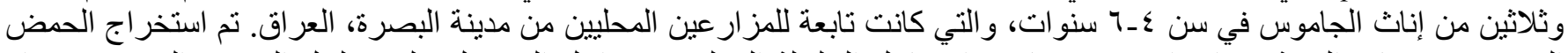

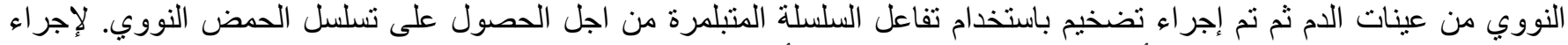

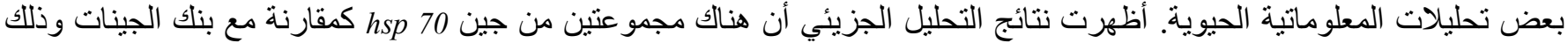

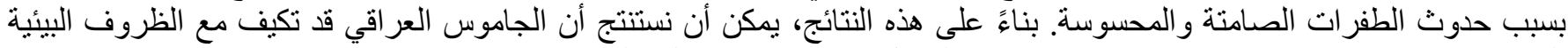

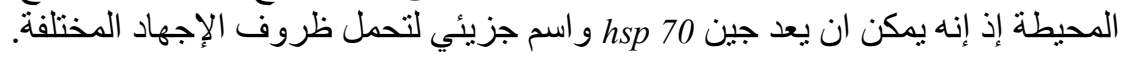

\section{Introduction}

The HSP 70 is a dominant protein member of the huge HSP family. This family has a diversity of functions in the cells such as protecting living cells under the different conditions of stress (1). Furthermore, the HSP 70 was specified to be a confirmatory molecular marker for determination the response of different stress conditions in the farm animals (2). The hsp 70 gene can be used as an elect gene for the election cattle based on the stress 
leniency traits (3). The hsp 70 gene is imperative to generate HSP 70 that influencing on the stress conditions (4). The HSP 70 has a molecular weight between $68-73$ KDa (5), composed 641 amino acid (6) and the coding region of the $h s p 70$ gene in buffalo with length 1926bp (7). Despite the HSP 70 is consider as a highly conserved polypeptide (8), the polymorphisms of the hsp 70 gene explain the variance between individuals in resistance to the different stress conditions. On one hand, the previous studies have reported the diversity of polymorphisms of the hsp 70 gene (9-15), as well as linked some of the different production traits (16-20). On the other hand, the variations in the DNA sequences are of value because they might change the interaction of the HSP 70, thus, enhancing the animal's response to the stress conditions (21). Buffaloes have significant economic importance of the different food industry in many developing countries of Asia that regards as one of the most important sources of milk and meat production (22). Iraq has the second largest number of buffaloes after Egypt in the Middle East region, it is also ranked globally as the $12^{\text {th }}$ of buffalos milk (23). In spite of the vital importance to buffaloes in Iraq, the environmental stress such as high temperatures (24), and the water salinity (25) have negatively affected on the production of buffalo. Therefore, there is an urgent need to look for mechanisms to resist the stress conditions and to select animals with a higher capacity to resist these conditions. The most important molecular mechanisms that the body possesses are the family of HSPs, especially HSP 70. It has important roles in protecting cells and keeping them alive when exposed to the different stress conditions (26), and the possibility of using its polymorphisms as an electoral marker to resist stress conditions (27).

Little is known about the adaptation mechanism of local Iraqi buffaloes for surviving in stress conditions and there is a lack of studies on this subject. Therefore, the current study was designed to determine the polymorphisms of the hsp 70 gene in the Iraqi buffaloes and study its role on the living cells in environmental stress.

\section{Materials and methods}

\section{Animal and Sampling}

This study was conducted during from November 2018 to February 2019. The number of the samples collected from buffalo females aged between 4-6 years old were 35 . All the samples were selected randomly at different stages of the milk production which belonged to local farms in Basra city, Iraq. The blood samples were collected from the jugular vein using sterile tubes with size $10 \mathrm{ml}$ containing $0.5 \mathrm{ml}$ EDTA solution as an anticoagulant, all samples were kept frozen at $-20^{\circ} \mathrm{C}$ till the DNA extraction process.

\section{DNA extraction}

The DNA was extracted from the blood samples using Genomic DNA Kit (Geneaid Biotech, Taiwan). Then it was estimated the concentration and the purity of DNA by using NanoDrop as described by Desjardins and Conklin (28).

\section{PCR Amplification}

The amplification reaction was $25 \mu \mathrm{l}$ containing $1.0 \mu \mathrm{l}$ DNA template $(75 \mathrm{ng}), 1.0 \mu \mathrm{l}$ Forward primer $(10 \mu \mathrm{M}), 1.0$ $\mu \mathrm{l}$ Revers primer $(10 \mu \mathrm{M}), 12.5 \mu \mathrm{l}$ of $2 \mathrm{X}$ PCR master mixes and $9.5 \mu \mathrm{l}$ water nuclease free. According to APICAL lab (formerly named First BASE Laboratories) Malaysia, the primer was used to amplify conserved coding region of the HSP 70 promoter (Table 1). PCR condition and thermal cycling protocols were summarized in Table 2. To detect PCR product was used $1.5 \%$ ethidium bromide $0.5 \mu \mathrm{g} / \mathrm{ml}$ stained agarose gel.

Table 1: The sequence of forward and reverse primer of $h s p$ 70 gene

\begin{tabular}{|c|c|}
\hline hsp70-F & ATGGCGAAAAACATGGCTATCGGC \\
\hline hsp70-R & СТАATCCACСТССТCAATGGTGGGGCC \\
\hline $\begin{array}{l}\text { APICAL } \\
\text { PCR pro }\end{array}$ & $\begin{array}{l}(\text { First } \\
\text { ize }=1926 \mathrm{bp})\end{array}$ \\
\hline
\end{tabular}

Table 2: Cycling protocol and temperature of PCR amplification

\begin{tabular}{llll}
\hline Cycle step & ${ }^{\circ} \mathrm{C}$ & Time & No. Cycles \\
\hline Initial Denaturation & 95 & $5 \mathrm{~min}$ & 1 \\
Denaturation & 94 & $30 \mathrm{~s}$ & \\
Annealing & 61 & $30 \mathrm{~s}$ & 30 \\
Extension & 72 & $2 \mathrm{~min}$ & \\
Final Extension & 72 & $10 \mathrm{~min}$ & 1 \\
\hline
\end{tabular}

\section{Sequence Analysis}

The sequence analysis was detected in APICAL (First BASE) Laboratories/ Malaysia. The BLAST analysis was carried out on website of NCBI. The Multiple Sequence Alignment (MAS) was done in http://www.ebi.ac.uk/Tools/msa/clustalo/. The result of sequence was compared with the Bubalus bubalis hsp 70 complete gene in GeneBank (Accession number EU099315.1) as a reference sequence. Mega - $\mathrm{x}$ version 10.0.5 (2018) software was used to characterization expected amino acids.

\section{Phylogenetic Tree Analysis}

The sequences were compared with the top 10 hits of the Bubalus bubalis hsp 70 gene in BLAST, represented by Accession numbers (EU099315.1, GU183098.1, GU183099.1, HM025989.2, KY912034.1, MF061305.1, 
MH814759.1, MH814760.1, MH814761.1, MH814762.1), then used the MEGA - X(29) for the analysis of phylogenetic tree.

\section{Results}

The ratio of 260/280 was between 1.80 to 1.85 for all samples. PCR product size was 1926 bp (Figure 1). Based on the analysis multiple sequence alignment, two different polymorphisms were obtained according to the mutations as compared to reference sequence (Accession number EU099315.1). They were divided in to Group 1 and Group 2.

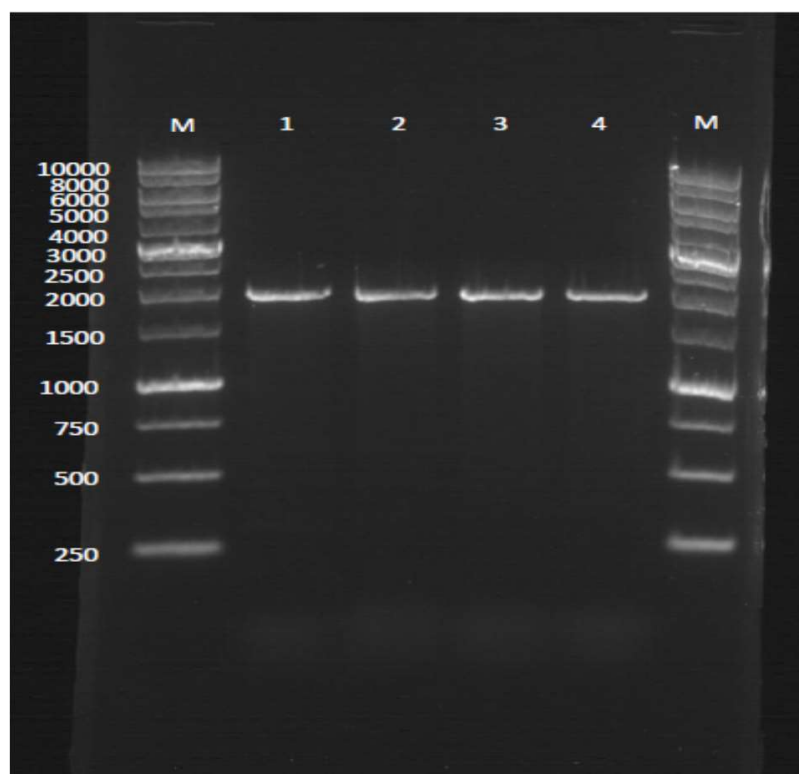

Figure 1: Gel electrophoresis of PCR products of the $h s p 70$ gene. M: DNA ladder 1000bp, 1-4 DNA templates.

\section{Group 1}

The position $235(\mathrm{G}>\mathrm{C})$ mutation, the position 364 $(\mathrm{A}>\mathrm{T})$ a missense mutation that occurred as a result of the change of amino acid from methionine to leucine. The position1079 $(\mathrm{A}>\mathrm{G})$, the position $1080(\mathrm{C}>\mathrm{T})$ both are missense mutations that occurred as a result of the change of amino acid from asparagine to serine. The position 1354 $(\mathrm{G}>\mathrm{A})$ a missense mutation that occurred as a result of the change of amino acid from aspartic acid to asparagine. The position $1638(\mathrm{C}>\mathrm{G})$ silent mutation and the position 1639 $(\mathrm{T}>\mathrm{A})$ a missense mutation that occurred as a result of the change of amino acid from phenylalanine to isoleucine (Record in GenBank by accession number LC496272).

\section{Group 2}

The position $35(\mathrm{G}>\mathrm{C})$ a missense mutation that occurred as a result of the change of amino acid from glycine to alanine. The position $156(\mathrm{C}>\mathrm{T})$ a missense mutation that occurred as a result of the change of amino acid from glycine to arginine. The position $235(\mathrm{G}>\mathrm{C})$ silent mutation, the position $364(\mathrm{~A}>\mathrm{T})$ a missense mutation that occurred as a result of the change of amino acid from methionine to leucine, position $562(\mathrm{~A}>\mathrm{T})$ silent mutation, the position $563(\mathrm{C}>\mathrm{T})$ a missense mutation that occurred as a result of the change of amino acid from threonine to leucine. The position1079 (A>G) and the position 1080 $(\mathrm{C}>\mathrm{T})$ are both missense mutations that occurred as a result of the change of amino acid from asparagine to serine. The position $1354(\mathrm{G}>\mathrm{A})$ is a missense mutation that occurred as a result of the change of amino acid from aspartic acid to asparagine. The position $1638(\mathrm{C}>\mathrm{G})$ is silent mutation and the position $1639(\mathrm{~T}>\mathrm{A})$ is a missense mutation that are occurred as a result of the change of amino acid from phenylalanine to isoleucine. All the mutations were clarified in figure 2, and the changes of amino acids were clarified in figure 3 . The phylogenetic tree analysis (Figure 4) showed very close affinity with all sequences of the Bubalus bubalis hsp 70 gene. However, it did not match another sequence, but they were closer to complete the $h s p$ 70 gene in Bubalus bubalis of water buffalo (Accession Number EU099315.1)

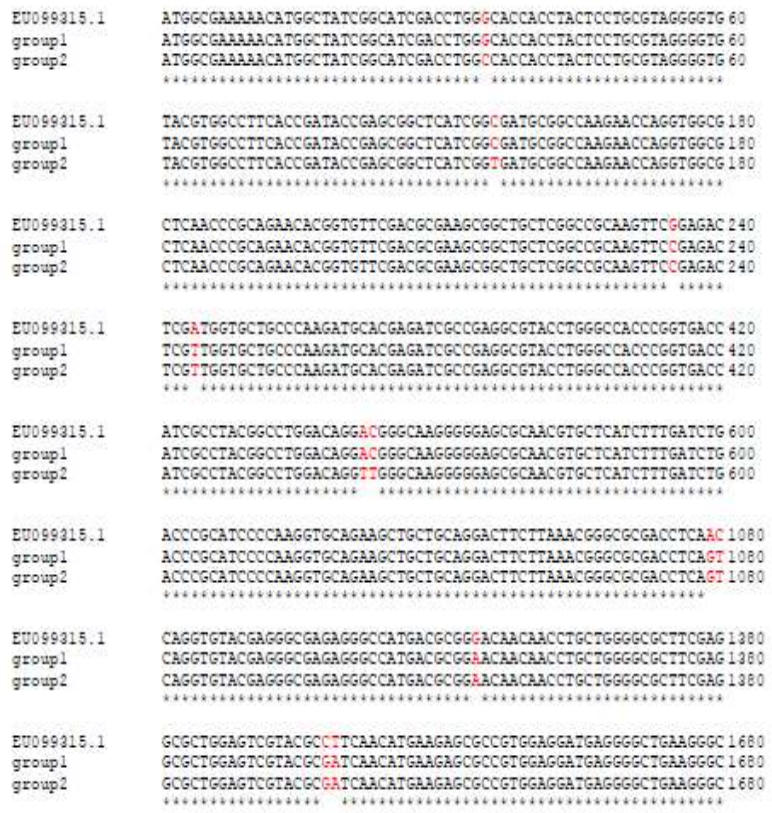

Figure 2: Mutations in the $h s p 70$ gene in Iraqi buffalo CLUSTAL O (1.2.4). EU099315.1: reference gene in GenBank. Group 1 and group 2: Sequences of the hsp 70 gene to Iraqi buffalo(Record in GenBank by accession number LC496273). 


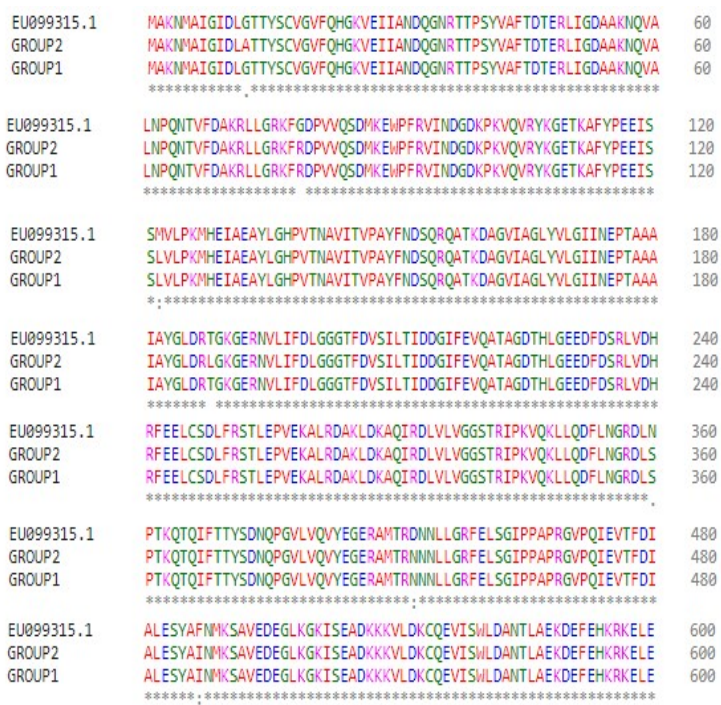

Figure 3: changes in amino acids to the $h s p 70$ gene to Iraqi buffalo as a compare with same gene in GenBank. EU099315.1: reference gene in GenBank. Group 1 and group 2: sequences: Sequences of the $h s p 70$ gene to Iraqi buffalo.

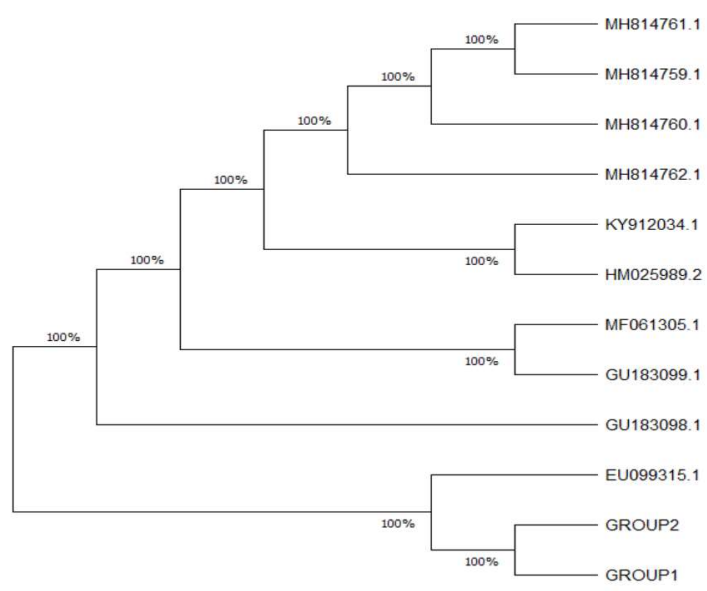

Figure 4: The Phylogenetic tree analysis of the $h s p 70$ gene in Iraqi buffalo. Group 1, 2: sequences of the $h s p 70$ gene in Iraqi buffaloEU099315.1, GU183098.1, GU183099.1, HM025989.2, KY912034.1, MF061305.1, MH814759.1, MH814760.1, MH814761.1, and MH814762.1: Accession numbers of top 10 hits Bubalus bubalis the hsp 70 gene sequences in GenBank

\section{Discussion}

The ratio of 260/280 was the best ratio for the purity of the DNA as mentioned (28). The results are in line with what $(7,19)$, noting the possibility of polymorphism for the hsp 70 gene in Buffalo, but the results did not match $100 \%$ with any pre-recorded GeneBank sequence, including the complete gene of the hsp 70 gene to Bubalus bubalis (Accession number EU099315.1). The corresponding ratio in the first group and the second group were 99.64 and $99.43 \%$ (30) respectively. This finding suggests that the Iraqi Buffaloes have different polymorphisms of the $h s p 70$ gene. The silent mutations can alter the capacity of an mRNA to code for protein via impact the average of the translation, by the change in codon usage through the production of budding protein (31). As for the missense mutations can be molecular markers to resist the heat stress $(32,33)$. This Genetic diversity may give Iraqi buffalo the ability to withstand various stress conditions (34). Moreover, the polymorphism in the coding region of the hsp 70 gene is associated with an advantage of longevity and survival, as well as the polymorphisms are correlated with increased heat tolerance (35). Nevertheless, the result of the Phylogenetic tree analysis is supporting the hypothesis that the Iraqi buffalo have adapted to environmental conditions, because these genetic changes can determine the ability of animals to withstand different stress conditions (7).

\section{Conclusion}

In conclusion, the current study showed two different groups of the $h s p 70$ gene, these differences may refer to the diversity of animals' ability to tolerate different stress conditions. Therefore, more studies to investigate the role of the polymorphism of the $h s p 70$ gene and the different production traits in the Iraqi buffalo are needed.

\section{Acknowledgments}

We extend our appreciation to the Associate Professor Dr. Wessam Monther Mohammed Saleh, college of Veterinary Medicine, university of Basra for his supporting, aiding, and direction in sampling process. Many gratitude and thanks to the farmers who cooperated with us to complete this work.

\section{References}

1. Nandlal PH. Studies on molecular and immunological characterization of heat shock protein 70 (HSP70) in buffaloes [PhD dissertation]. Ludhiana: Institutional Repository of Indian National Agricultural Research System; 2012. 22-78 p.

2. Sejian V, Bhatta R, Gaughan J, Malik PK, Naqvi SMK, Lal R. Adapting sheep production to changing climate: Conclusions and researchable priorities, in sheep production adapting to climate change. $1^{\text {st }}$ ed. Singapore: Springer; 2017. 431-441 p. Doi.org/10.1007/978-981-10-4714-5_21

3. Archana PR, Aleena J, Pragna P, Vidya MK, Niyas APA, Bagath M, Sejian V. Role of heat shock proteins in livestock adaptation to heat 
stress. J Dairy Vet Anim Res. 2017;5(1):00127. Doi:10.15406/jdvar.2017.5.00127.

4. Mohanarao GJ, Mukherjee A, Banerjee D, Gohain M, Dass G, Brahma B, De S. HSP70 family genes and HSP27 expression in response to heat and cold stress in vitro in peripheral blood mononuclear cells of goat (Capra hircus). Small Rumin Res. 2014;116(2-3):94-99. Doi.org/10.1016/j.smallrumres.2013.10.014.

5. Pockley AG, Muthana M, Calderwood SK. The dual immunoregulatory roles of stress proteins. Trends Biochem Sci. 2008;33(2):71-79.Doi:10.1016/j.tibs.2007.10.005

6. Gade N, Mahapatra RK, Sonawane A, Singh VK, Doreswamy R, Saini M. Molecular characterization of heat shock protein 70-1 gene of goat (Capra hircus). Mol Biol Int. 2010;2010. Doi.org/10.4061/2010/108429.

7. Sodhi M, Mukesh M, Kishore A, Mishra BP, Kataria RS, Joshi BK. Novel polymorphisms in UTR and coding region of inducible heat shock protein 70.1 gene in tropically adapted Indian zebu cattle (Bos indicus) and riverine buffalo (Bubalus bubalis). Gene. 2013;527(2):606-615.Doi: 10.1016/j.gene.2013.05.078.

8. Goodman SC, Letra A, Dorn S, Araujo AC, Vieira AE, de Souza LC, Silva RM. Expression of heat shock proteins in periapical granulomas. J Endod. 2014;40(6):830-836.Doi: 10.1016/j.joen.2013.10.021.

9. Rosenkrans Jr, Banks A, Reiter S, Looper M. Calving traits of crossbred Brahman cows are associated with heat shock protein 70 genetic polymorphisms. Anim Reprod Sci. 2010;119(3-4):178-182. Doi: 10.1016/j.anireprosci.2010.02.005.

10. Basirico L, MoreraP, Primi V, Lacetera N, Nardone A, Bernabucci U, Cellular thermotolerance is associated with heat shock protein 70.1 genetic polymorphisms in Holstein lactating cows. Cell Stress Chaperones. 2011;16(4):441-448. Doi: 10.1007/s12192-011-0257-7.

11. Turner CM, Brown Jr, Brown MA, Steelman CD, Rosenkrans JrF. Associations among heat shock protein 70 genotype, forage system, and horn-fly infestation of beef cattle. Prof Anim Sci. 2013;29(3):237241. Doi.org/10.15232/S1080-7446(15)30229-1.

12. Ramesha KP, Basavaraju M, Geetha GR, Rao A, Hatkar DN, Kataktalware MA, Suresh KP, Anantharaj A, Das DN, Divya P. Polymorphism in the promoter region of the hsp 70 gene and its association with performance traits in Deoni cattle. Indian J Anim Sci. 2016;86(12):1466-1468.

13. Oner Y, Keskin A, Ustuner H, Soysal D, Karakaş V. Genetic diversity of the $3^{\prime}$ and $5^{\prime}$ untranslated regions of the HSP70. 1 gene between native Turkish and Holstein Friesian cattle breeds. South Afr J Anim Sci. 2017;47(4):424-439. Doi.org/10.4314/sajas.v47i4.2.

14. Habib HN, Hassan AF, Khudaier BY. Molecular detection of polymorphism of heat shock protein 70 (hsp70) in the semen of Iraqi Holstein bulls. Asian J Anim Sci. 2017;11:132-139. Doi:10.3923/ajas.2017.132.139

15. Fatima F, Nadeem A, Javed M. Molecular characterization of heat shock protein 70-1 gene of Capra aegagrus blythi. Pakistan J Zool. 2019;51(1):1-7.Doi:10.17582/journal.pjz/2019.51.1.195.203.

16. Cheng W, Li Q, Wang C, Wang H, Li J, Sun Y, Zhong J. Genetic polymorphism of HSP70-1 gene and its correlation with resistance to mastitis in Chinese Holstein. Yi chuan Hereditas. 2009;31(2):169-174. Doi:10. 3724/sp.j.1005.2009.00169.

17. Du FL, Wang HM, Huang JM, Li JB, Zhong JF, Zhang TR, Wang CF. Polymorphism at 3'-UTR of the heat shock protein 70 gene and its relationship with thermal tolerance in Chinese Holstein. Acta Agri Sci. 2010;3:5. Doi: 10.7668/hbnxb.2010.03.004.

18. Deb R, Sajjanar B, Singh U, Kumar S, Brahmane MP, Singh R, Sharma A. Promoter variants at AP2 box region of Hsp70. 1 affect thermal stress response and milk production traits in Frieswal cross bred cattle. Gene. 2013;532(2):230-235. Doi:10. 1016/j.gene.2013.09.037.

19. Gafer JA, El-Rahman GHA, Rawash Z. Association of hsp 70 Gene polymorphism and bull semen quality in winter and summer seasons. Alexandria J Vet Sci. 2015;1:46. Doi: 10.5455/ajvs.186038.

20. Habib HN, Khudaier BY, Hassan AF, Saleh WM. The Association of the polymorphism and gene expression of heat shock protein hsp 70 gene in winter and summer in the semen of Holstein bulls born in Iraq. Basrah J Vet Res. 2018;17:3.

21. Bhat S, Kumar P, Kashyap N, Deshmukh B, Dige MS, Bhushan B, Singh G. Effect of heat shock protein 70 polymorphism on thermotolerance in Tharparkar cattle. Vet World. 2016;9(2):113.Doi:10 .14202/vetworld.2016.113-117.

22. Nada AS, Nakao T. Role of buffalo in the socioeconomic development of rural Asia: Current status and future prospectus. Anim Sci J. 2003;74(6):443-455.Doi.org/10.1046/j.1344-3941.2003.00138.x

23. FAO. Food and Agriculture Organization Statistics. 2005; http://faostat.fao.org/default.aspx. Rome, Italy.

24. Alejandro CI, Abel VM, Jaime OP, Pedro SA. Environmental stress effect on animal reproduction. Op J Anim Sci. 2014;4(02):79. Doi: 10.4236/ojas.2014.42011.

25. Alam MZ, Carpenter L, Mitra S, Haque M, Halsey J, Rokonuzzaman $M$, Moniruzzaman M. Effect of salinity intrusion on food crops, livestock, and fish species at Kalapara Coastal Belt in Bangladesh. J Food Qual. 2017;2017. Doi.org/10.1155/2017/2045157

26. Calderwood K. Cell stress proteins. $1^{\text {st }}$ ed. New York: Springer; 2007. 281-312 p. Doi.org/10.1007/978-0-387-39717-7.

27. Srikanth K, Kwon A, Lee E, Chung H. Characterization of genes and pathways that respond to heat stress in Holstein calves through transcriptome analysis. Cell Stress Chaperones. 2017;22(1):2942.Doi:10. 1007/s12192-016-0739-8

28. Desjardins P, Conklin D. NanoDrop microvolume quantitation of nucleic acids. J Vis Exp. 2010;45:2565. Doi: 10.3791/2565.

29. Kumar S, Stecher G, Li M, Knyaz C, Tamura K. MEGA X: molecular evolutionary genetics analysis across computing platforms. Mol Biol Evol. 2018;35(6):1547-1549.Doi.10. 1093/molbev/msy096.

30. Sievers F, Desmond GH. Clustal omega. Curr Prot Bioinform. 2014;48(1):3-13. Doi: 10.1002/0471250953.bi0313s48.

31. Kimchi C, Oh JM, Kim IW, Sauna ZE, Calcagno AM, Ambudkar SV, Gottesman MM. A silent polymorphism in the MDR1 gene changes substrate specificity. Sci. 2007;315(5811):525-528.Doi:10. 1126/science. 1135308

32. Kumar R, Gupta ID, Verma A, Verma N, Magotra A, Vineeth MR. Molecular characterization and polymorphism detection in HSPB6 gene in Sahiwal cattle. Indian J Anim Res. 2015;49(5):595-598. Doi: 10.18805/ijar.5568

33. Silva CF, Sartorelli ES, Castilho ACS, Satrapa RA, Puelker RZ, Razza EM, Barros C. Effects of heat stress on development, quality and survival of Bos indicus and Bos taurus embryos producedin vitro. Theriogenol. 2013;79(2):351-357.

34. Onasanya GO, Ikeobi CO, Ayotunde AS, Oke FO, Olorunisola RA, Decampos JS. Thermo-regulatory functions of heat shock protein genes in some selected tropically stressed livestock animals. Inter J Appl Res Technol. 2017;6(8):37-43.

35. Singh R, Kolvraa S, Bross P, Jensen UB, Gregersen N, Tan Q, Rattan SI. Reduced heat shock response in human mononuclear cells during aging and its association with polymorphisms in HSP70 genes. Cell Stress Chaperones. 2006;11(3):208.Doi: 10.1379/csc-184r.1. 